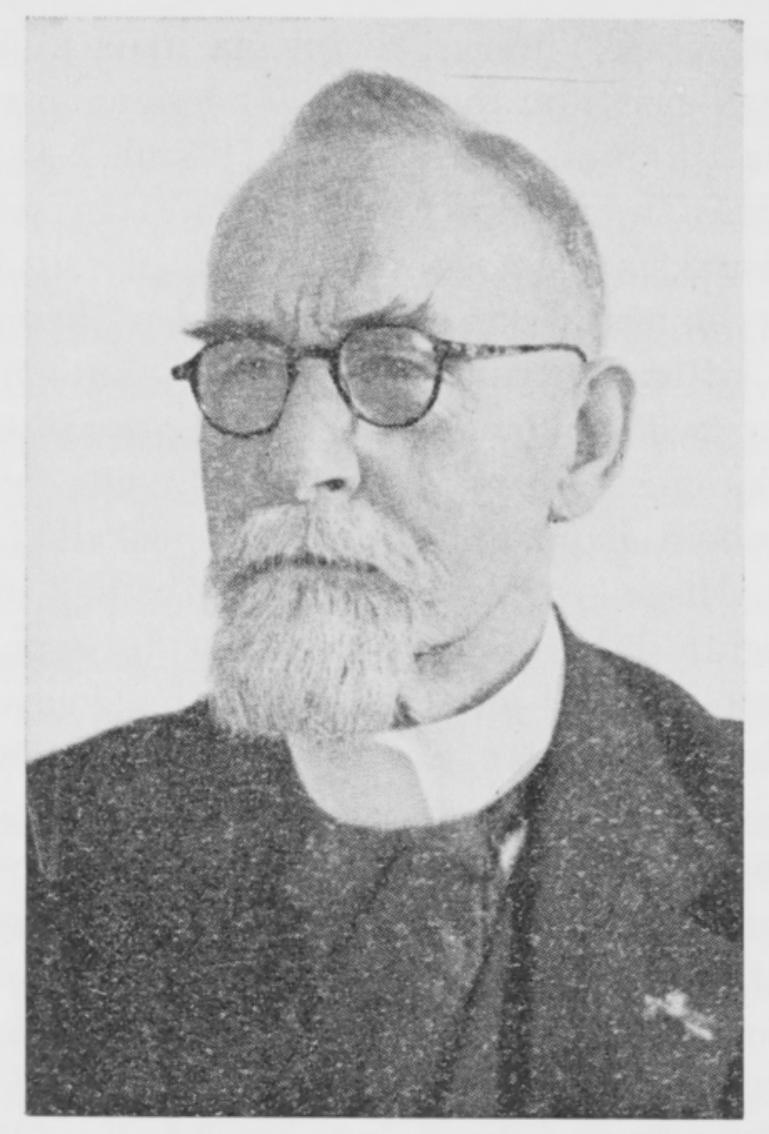

\title{
D. J. HISSINK
}

$$
\text { *22. 10. } 1874-\dagger \text { 17. 1. } 1956
$$

Suomen Maataloustieteellisen Seuran kirjeenvaihtajajäsen, hollantilainen maaperäntutkija, filosofian tohtori David Jacobus Hissink kuoli 17. 1. 1956. Hän oli syntynyt 22. 10. 1874 Kampenin kaupungissa Hollannissa. Hän opiskeli Amsterdamissa kemiaa ja väitteli tohtoriksi 1899. Oltuaan pari vuotta opettajana kotimaassaan Hissink siirtyi Jaavalle Buitenzorgin koeasemalle. Siellä hän suoritti arvokkaita maaperätutkimuksia, mutta joutui terveydellisistä syistä palaamaan jo v. 1903 kotimaahansa. Seuraavana vuonna hän tuli Goesin maatalouskoelaitoksen kemistiksi ja pian laitoksen johtajaksi. V. 1907 hän siirtyi samanlaiseen tehtävään Wageningeniin ja 1915 Groningeniin. Tästä kaupungista tuli sittemmin hänen työpaikkansa, sillä jo seuraavana vuonna hänet nimitettiin silloin perustetun Groningenin maatutkimuslaitoksen johtajaksi, jossa toimessa hän pysyi eläkkeelle siirtymiseensä saakka.

Hissinkin ensimmäiset puhtaasti maaperätieteelliset tutkimukset käsittelivät erilaisten suolojen vaikutusta maan vedenläpäisykykyyn, ja ne ovat olleet suuntaa antavia hänen myöhemmälle tutkimustyölleen. Hissink nimittäin lienee ensimmäinen henkilö, joka käsitti mikä merkitys vaihtuvilla ioneilla ja erityisesti Na- 
ionilla on maan rakenteeseen. Viimeksi mainittua ionia kulkeutui meriveden mukana tulvan alaisille maille erittäin runsaasti. Johdonmukaisena seurauksena näistä jo v. 1906 suoritetuista tutkimuksista oli, että Hissink keskittyi entistä enemmän maassa tapahtuvan emästen vaihdon tutkimiseen. Hän selvitteli erilaisten Hollannin maiden ominaisuuksia tässä suhteessa. Hänen esittämänsä menettelytapa ja erityisesti eri ioniryhmien keskinäisten suhteiden ilmoittaminen käyttämällä S-, T- ja V-arvoja on sittemmin tullut yleisesti käytäntöön.

Ionien vaihdon ja kyllästysasteen kanssa läheisessä suhteessa olevan maan happamuusasteen tutkiminen liittyi sitten 1920-luvulla hyvin luontevasti Hissinkin työkenttään, jolloin happamuuskysymys oli kaikkialla hyvin keskeisenä tutkimuksen kohteena. Hissink on van der Spekin kanssa julkaissut monia erityisesti Hollannin maaperän happamuutta koskevia tutkimuksia.

Toinen tutkimuksen kohde, jota Hissink voimakkaasti harrasti, oli uusien pengerrettävien alueiden maapohjan käyttöarvon määrittely. Tällaisia tutkimuksia hän suoritti aluksi pienehköjen järvien ja soiden kuivatustöiden yhteydessä, mutta pian hänen työnsä sai erittäin suurpiirteisen luonteen. Hänen toimestaan ryhdyttiin nimittäin suorittamaan vedenalaisia maaperätutkimuksia ennen Zuiderseen patoamiseen ryhtymistä. Samanlaisia tutkimuksia on sittemmin suoritettu Wieringermeren ja Koillispolderin kuivatusta silmällä pitäen. Näiden tutkimusten ansiosta voitiin kuivattavien alueiden tulevaa käyttöä jo yksityiskohtaisesti suunnitella samaan aikaan kun niiden pengerrystyöt olivat käynnissä. Paitsi maan yleisiä käyttömahdollisuuksia on tällaisella etukäteen suoritetulla yksityiskohtaisella maantutkimuksella voitu selvitellä myös eri alueiden suolapitoisuutta, jolla on erittäin keskeinen merkitys uusien merestä vallattavien viljelysmaiden käyttöarvoon.

Zuiderseen pohjamaiden luonteen selvittely edellytti monenlaisia tutkimuksia. Niinpä Hissink niiden yhteydessä apulaisineen kehitteli maan mekaanista analyysiä ja kiinnitti huomiota niihin kemiallisiin ja fysikaalisiin muutoksiin, joita maassa tapahtui sen kuivumisen johdosta. Tällä tavalla tulivat perusteellisesti tutkituiksi ne monenlaiset ilmiöt, joiden vaikutuksesta merelliset sedimentit saadaan muuttumaan hyvätuottoisiksi peltomaiksi.

Zuiderseen pohjamaita koskevaan tutkimustyöhön liittyi vielä laaja selvittely tämänlaatuisten maiden kuivatuksen tarpeesta. Tämä työ tapahtui hyvin suuressa määrin laajana yhteistyönä monien saksalaisten ja ranskalaisten tutkijoiden kanssa ja se oli omiaan kehittämään Groningenin maantutkimuslaitoksesta kansainvälisesti tunnetun tutkimuskeskuksen.

Hissinkillä oli tieteellisen työnsä ohella erittäin voimakas harrastus kansainväliseen yhteistyöhön. Jo ennen ensimmäistä maailmansotaa hän oli v. 1912 mukana Tukholmassa pidetyssä kansainvälisessä maantutkimuskonferenssissa ja sodan päätyttyä hän työskenteli innokkaasti kansainvälisten siteiden uudelleen solmiamiseksi. Niinpä v. 1922 pidettiin Prahassa kansainvälinen maantutkimuskonferenssi, ja v. 1924 Roomassa pidetyssä kokouksessa perustettiin erityinen kansainvälinen maantutkimusseura, jonka sihteeriksi ja varapuheenjohtajaksi saatiin heti alusta pitäen Hissink. Seuran puheenjohtaja valittiin joka viiden vuo- 
den kuluttua uudelleen, mutta sihteeri sitävastoin oli pysyväinen ja sen johdosta Hissinkistä muodostuikin tämän suuren seuran keskeisin henkilö. Hän ylläpiti ja lujitti eri kansojen ja tutkijoiden välistä kanssakäymistä sekä valmisti erittäin ansiokkaasti konferensseja ja kongresseja. Käytännöllisesti katsoen hän oli mukana kaikissa kansainvälisissä maantutkijain kokouksissa aina vuoteen 1950 saakka. Groningenin maatutkimuslaitos muodostui tämän kansainvälisen yhteistoiminnan keskipisteeksi. Osoituksena siitä vilkkaudesta, jolla kansainvälinen maantutkimusseura työskenteli voidaan mainita, että v. 1924 ja 1939 välillä sen toimesta pidettiin kolme laajaa kansainvälistä maantutkimuskongressia ja kymmenen suppeampaa konferenssia, viimeksi mainituista yksi Suomessa v. 1938.

Toinen maailmansota aiheutti jälleen keskeytyksen niin maaperän kuin muidenkin tutkijoiden kansainvälisessä yhteistyössä. Mutta Hissink, huolimatta siitä että hän oli 1939 tullut täysin palvelleeksi, ryhtyi sodan päätyttyä jälleen voimakkaasti kehittämään yhteistoimintaa, ja jo v. 1950 yli 700 maaperäntutkijaa eri puolilta maapalloa kokoontui Amsterdamiin neljänteen kansainväliseen kongressiin. Kongressipaikaksi oli valittu Hollanti paitsi maan neutraalin luonteen ja sen monien tämän alan etevien edustajien vuoksi myös sen takia, että haluttiin kunnioittaa Hissinkin arvokasta elämäntyötä. Tässä kongressissa hänet kutsuttiin Kansainvälisen maantutkimusseuran kunniajäseneksi.

Hissink oli erittäin miellyttävä ihminen ja sen johdosta hän sai paljon ystäviä kaikkialla missä hän liikkui. Hän oli toisaalta intomielinen ja omaksumaansa asiaa tai käsitystä hän ajoi voimakkaasti. Taitavana puhujana, joka hallitsi täydellisesti englantia, ranskaa ja saksaa, hän kykeni tuomaan mielipiteensä ja tutkimustensa tulokset selvästi esille. Hän oli lisäksi mainio organisaattori, ja se taito tuli näkyviin juuri kansainvälisessä yhteistyössä. Tämän yleistä kunnioitusta nauttineen monipuolisen ja taitavan tutkijan kuolema tunnetaan suurena menetyksenä kaikkialla maaperätutkijoiden keskuudessa. 